\title{
CONTROVERSY IN SURFACE RIGHTS COMPENSATION: PATTERN OF DEALINGS EVIDENCE AND GLOBAL AWARDS
}

\author{
BARRY BARTON*
}

\begin{abstract}
This paper investigates the rival "four heads" and "global" approaches to fixing compensation under the Surface Rights Act of Alberta. The global approach involves two issues: the use of evidence of a pattern of negotiated dealings in the district, and the assessment of compensation in one lump sum.
\end{abstract}

\section{INTRODUCTION}

Recent changes of approach in fixing compensation have created a state of turmoil in Alberta surface rights law. The Surface Rights Act' governs the rights of operator companies to enter on private lands and use them for oil and gas wells, pipelines, power transmission lines and similar purposes. Land owners and operators have adopted widely diverging approaches to the way that the compensation payable to the owner for these rights of entry should be calculated. Owners have been advancing what has loosely been called the "global" approach, while operators have defended what is known as the "four heads" approach. These differences have resulted in conflicting decisions by the Surface Rights Board, and also in the courts, which are handling more surface rights cases than any other type of oil and gas litigation. The purpose of this paper is to find a way through the confusion that has resulted, and to make some suggestions about how it might be reduced.

Procedures and principles under the Surface Rights Act have been described elsewhere, ${ }^{2}$ but some of the main features may be mentioned by way of background. The current Act is the result of a revision in 1983, but the revision did not alter the basic structure of the Act, and did not affect the issues that are of interest here. Section 12 of the Act prohibits an operator from entering the surface of any land until he has obtained the consent of the owner and the occupant of the land by a surface lease or right-of-way agreement, or until he has obtained a right of entry order from the Surface Rights Board. However, if the operator has already obtained a well licence or similar approval from the Energy Resources Conservation Board, a right of entry order is granted by the Surface Rights Board as a matter of routine. The Surface Rights Board's main task is to hold a hearing to determine the amount of compensation payable and to make a compensation order to that effect. The Act gives the Board a wide discretion in fixing compensation. The key section, s. 25(1), is permissive rather than imperative. It states:

The Board, in determining the amount of compensation payable, may consider

(a) the amount the land granted to the operator might be expected to realize if sold in the open market by a willing seller to a willing buyer on the date the right of entry order was made,

* Research Associate, Canadian Institute of Resources Law, University of Calgary, Calgary, Alberta.

1. S.A. 1983, c. S-27.1.

2. Currie, "Compensation for Oil and Gas Surface Rights in Albera" (1971) 36 Sask. L. Rev. 350, and like-titled articles by Lucas (B.C.) p. 369 and Sychuk (Sask.) p. 387; Ridsdel and Bennett, A Guide to Appearing Before the Surface Rights Board of Alberta, Calgary, Canadian Institute of Resources Law, 1982; Richards and Price "Surface Rights Acquisition and Compensation", (1982) 20 Alta. L. Rev. 1. 
(b) the per acre value, on the date the right of entry order was made, of the titled unit in which the land granted to the operator is located, based on the highest approved use of the land,

(c) the loss of use by the owner or occupant of the area granted to the operator,

(d) the adverse effect of the area granted to the operator on the remaining land of the owner or occupant and the nuisance, inconvenience and noise that might be caused by or arise from or in connection with the operations of the operator,

(e) the damage to the land in the area granted to the operator that might be caused by the operations of the operator, and

(f) any other factors that the Board considers proper under the circumstances.

The other subsections in $s .25$ cover other aspects of compensation, again in a permissive manner for the most part. Costs are fixed in the discretion of the Board. The prevailing practice is for the operator to be ordered to pay the owner's costs. The only other point that needs to be mentioned is the unrestricted right of an owner or operator to appeal a compensation order to the Court of Queen's Bench under s. 26. The appeal is to be in the form of a new hearing, but it has been settled by the Supreme Court of Canada that the Board's special knowledge and expertise is to be given considerable weight. This is the rule in Lamb v. Canadian Reserve Oil and Gas Ltd. ${ }^{3}$ and Caswell v. Alexandra Petroleums Ltd. ${ }^{4}$

\section{THE DIFFERENT APPROACHES}

The Board distinguishes between compensation for losses that only occur in the first year and losses that recur from year to year. Under this main distinction, the Board has customarily followed the practice of grouping the various different items of compensation under four headings, two for first year compensation and two for annual compensation. These four heads are (i) the value of the interest taken, (ii) general disturbance, (iii) loss of use and (iv) adverse effect. They do not form an exact or comprehensive classification, and their terminology is not as precise as in the Act. They are no more than a convenient framework for separating out the different issues involved in compensation. They may be varied with the needs of the case, by dropping one or another head, or by considering separately some item such as the special value of the land to the owner, or damage caused to the land. For each head, the Board hears evidence from the parties and their witnesses about the values and losses concerned. The parties suggest figures for each item, and the Board decision follows the same method, fixing a figure for each head. The final award is the sum of those figures. This approach has become known, especially by its detractors, as the "four heads" approach.

The alternative method that has developed rejects the division of compensation into categories that can be calculated separately. Such factors are highly inter-related, and one must look at the overall effect of the operator's activities on the landowner. This is often referred to as the "global" approach. Compensation is ascertained by referring to the levels of compensation being set by voluntary negotiations between landowners and operators. If there are enough voluntary agreements to show that there is a pattern of dealings in the district, then the Board can 
[VOL. XXIV, NO. 1

follow that pattern in fixing a figure for first-year compensation and for annual compensation where appropriate. The rationale is that no matter how expert outsiders such as appraisers or even the Board itself may be, the oil companies and landowners have the better judgment as to what compensation should be paid in their own interest. ${ }^{5}$ There is a market of sorts in surface rights, and the Board's compensation awards should accord with the prices set in that market. Using this approach calls for the collection of enough suitable agreements to establish a pattern. Often six or a dozen may be relied on, but in one group of hearings more than eight hundred were assembled. 6

The growth of this latter approach at the expense of the "four heads" approach obviously owes much to the belief of landowners that more compensation is to be won this way. The increasing accumulation of a large number of negotiated surface leases and right-of-way agreements must also be a factor. So too must be the development of Surface Rights Groups in many parts of the province since the mid-seventies. These groups are informal organizations of farmers and other landowners whose purposes are to collect information on dealings with operators in the area, to advise farmers on appropriate rates of compensation, and on occasion to try to establish fixed group rates regardless of variations in land use and individual problems. Behind these groups, and also behind some Board decisions, is a belief that compensation must be set equitably, if not equally, between landowners. Also evident is a suspicion that it is impossible to fix compensation with any certainty by using calculations that are becoming more and more complicated, with analyses of land values, residual values, injurious affection and the like. Expert appraisal evidence is being met with a certain amount of distrust.

\section{THE ISSUES}

This newer approach to compensation is not a single issue; it actually comprises two entirely distinct issues which get blurred as the arguments sway to and fro. The first issue is the use of evidence of negotiated agreements in the area instead of evidence about land values, adverse effect and the like. This may be termed the question of "pattern of dealings" evidence, to use the language of the leading case, Livingston v. Siebens Oil and Gas Ltd. ${ }^{7}$ It is a question about evidence, or about the relevance of certain facts to the determination of compensation. The second issue is the assessment of compensation in a lump sum, in an effort to consider many inter-related factors together, rather than estimating figures for different types of loss separately. This is the question of the "global" award, being a question about the method of reasoning that should be used in fixing compensation. Both the "pattern of dealings" approach and the "global" award are departures from the "four heads" approach, and both are sometimes imprecisely included in a reference to "the global approach", but in reality they deal with very different matters.

5. Per McDermid J.A. in Livingston v. Siebens Oil and Gas Ltd. [1978] 3 W.W.R. 484 at 490 (Alta. App. Div.).

6. Dome Petroleum Lid.v. Oatway, S.R.B. Decision E184/84.

7. Supran. 5. 
Useful though it is to distinguish between the "pattern of dealings" approach to evidence and the making of an award on a "global" basis, the existence of a close connection between the two is obvious. The reason for it lies in the fact that privately-negotiated agreements have not generally broken compensation down in the same way as the Surface Rights Board does in using its four heads approach. Indeed, many pipeline right-of-way agreements simply provide for one lump sum as a consideration, and many surface leases provide one sum for the first year and a lower sum thereafter as an annual rental. ${ }^{8}$ When the Board relies on a pattern of such private dealings to make its award, it cannot tell how much the parties had in mind for each of the four heads that it usually uses, and is therefore obliged to follow suit with an award of compensation in one undifferentiated lump sum. Thus, pattern of dealings evidence tends to result in a global award.

\section{LEGAL AUTHORITY FOR THE PATTERN OF DEALINGS APPROACH}

At this point we will consider the pattern of dealings approach in isolation from the global awards question, concentrating on the question of the legal validity of the approach rather than whether or not it is a desirable technique. The initial point of reference must of course be what the Surface Rights Act says about a pattern of dealings approach. Unfortunately, the Act is silent on the subject. Section 25(1) is permissive, in that the Board, "in determining the amount of compensation payable, may consider" a list of factors, without any direction that it shall consider them. The list is open rather than closed, in that the Board may consider any other factors as well as the specified factors. Further, it is quite reasonable to suggest that the Board can and does consider the specified factors even when the evidence it is hearing is evidence of a pattern of dealings. The Act makes no rules about the type of evidence that the Board may receive. On the contrary, s. $8(3)(\mathrm{b})$ provides that the Board is not bound by the rules of law concerning evidence. Nor does the Act contain any general statement of principles which govern the fixing of compensation, such as is found in the Expropriation $\mathrm{Act}^{9}$ or in the surface rights legislation of British Columbia. ${ }^{10}$ Since the Act neither confirms nor denies the validity of the pattern of dealings approach, there is plenty of scope for judicial rulemaking.

The pattern of dealings approach is no newcomer to the Surface Rights Board and the courts. It first appeared in Twin Oils Ltd. v. Schmidt, ${ }^{11}$ one of the first appeals from a Board order, in 1968. There, Feir C.J.D.C. heard evidence from two farmers each of whom had negotiated

8. There is, however, a trend towards a greater itemization of amounts being paid for individual heads. The 1983 Alberta Right of Way Agreement, a standard form drafted in negotiations between farm and industry representatives under the chairmanship of the Office of the Farmers' Advocate, provides for the parties to itemize the calculation of compensation under the four heads that the Surface Rights Board uses. The same is provided for in a new edition of the Alberta Surface Lease Agreement that is now being drafted.

9. R.S.A. 1980 , c. E-16, s. 42(2).

10. Petroleum and Natural Gas Act, R.S.B.C. 1979 , c. 323 , s. $9(2)$.

11. (1968) 74 W.W.R. 647 (Alta. D.C.). 
several rights of entry onto his land. These revealed that "a market of sorts has been established for rights of entry" and displayed a remarkably even trend in compensation levels. ${ }^{12}$ However, what would now be called a four heads approach was the main line of reasoning used to determine compensation, with the pattern of dealings evidence being no more than a confirmation of its accuracy.

The pattern of dealings approach was more directly in issue in the Appellate Division in Great Plains Development Co. of Canada v. Lyka, ${ }^{13}$ in 1973. The Board considered that the evidence tendered by the parties on the value of the land was worthless, so it turned to negotiated agreements that it had on file as the best and only evidence available. On appeal to the District Court, the Judge rejected this evidence as not having the same weight as sales on a truly open market free of the threat of expropriation; ${ }^{14}$ but on further appeal the Appellate Division held that this evidence of settlements respecting pipeline easements in the district should have been considered. This decision was cited and followed in 1977 by District Court Judge Medhurst in Roen v. PanCanadian Petroleum Ltd. ${ }^{15}$ The evidence presented was found to be far from conclusive or satisfactory, especially on the owner's side. However the company landman gave evidence that his offer to the owner was the general of fer made in the district, that he had negotiated some fifteen agreements on that basis, and that it was similar to a package agreement he had negotiated with the Eastern Irrigation District. The Board's award was lower than these figures suggested. Medhurst D.C.J. said: ${ }^{16}$

\footnotetext{
Nevertheless, I believe that as far as possible all owners of land in an area should be treated in the same manner in determining compensation. If there are a number of negotiated agreements then the amounts agreed upon should be taken into consideration.
}

The agreed amounts seemed fair and were used for the award to the owner. The amount awarded was broken down to indicate how much was attributed to each of the four heads of compensation.

These earlier cases, however, have been completely overshadowed by Livingston v. Siebens Oil and Gas Ltd. ${ }^{17}$ Livingston concerned well sites in the same locality as the Roen case, and the evidence was similar but more extensive. The operator informed the Board of compensation in leases that it and two other companies had negotiated, and of rules established by the Eastern Irrigation District. The landowner contended that the District had recently increased its rates, and he and a neighbour gave evidence of a number of other surface agreements on their lands. The Board did not consider that these amounts were evidence of what should be paid; the circumstances under which they were derived were not known and, accordingly, the amounts were "meaningless". ${ }^{18}$ On ap-

12. Id. at 659.

13. [1973] 5 W.W.R. 768 (Alta. S.C.A.D.).

14. [1972] 6 W.W.R. 321.

15. (1977) 12 L.C.R. 143.

16. Id. at 149.

17. Supran. 5.

18. Id. at 487. 
peal, Medhurst D.C.J. again found a general pattern of transactions and held that the pattern should have been taken into account. He increased the Board's awards to $\$ 1,600$ for the first year and $\$ 600$ for the following years for each of the four wells; the same figures he had awarded in Roen.

The operator took the case to the Appellate Division, but the appeal was dismissed. The Appellate Division held that the District Court Judge had been correct in rejecting the awards set by the Board, since the Board had failed to weigh and had rejected relevant evidence, the evidence of what was being paid in the area. On the basis that the Board would have had to raise the amounts to be paid at least to the amounts set by the District Court Judge, the Judge's award was left undisturbed. This being the leading case, it is desirable to quote extensively from McDermid J.A., who delivered the Court's judgment: ${ }^{19}$

When the cases and legislation concerning surface rights are considered it is apparent that there have been political overtones as to what an oil company should pay the sur. face rights owner. In many mineral titles there was a reservation of a right to work the minerals. Notwithstanding, the legislature intervened and provided that even in such cases the surface owner must be compensated. Originally, in Turner Valley when the first oil well was brought into production in the 1930's, there was a standard rate for a ten-acre parcel of $\$ 500$ for the first year and $\$ 100$ annually. However, this did not last very long as the industry expanded throughout the province. There has been agitation that the surface owner should have a gross royalty. Keeping in mind this political background, it is most important that when both parties have shown that they are satisfied by establishing a course of dealing in any area this is very relevant evidence to be considered by the board. The company may in an individual case pay more than it thinks is fair, for various reasons, and, as the board states, little weight can be given to individual cases, but, in an area where there is a course of dealings between oil companies and surface owners whereby a standard rate of compensation has been paid and accepted, this evidence should at the very least be given great weight by the board.

...

Cuunsel for the respondent landowner quoted to us from a decision of the board, No. $73 / 37 \mathrm{E}$, where the board said:

"The Board is of the opinion that, in the absence of evidence as to the market value of parcels of land similar in nature to the area of land expropriated, prices generally being paid by companies for acquisition of rights of way in the area, and in comparable areas, are a measure of the worth of the land in the minds of the parties to the acquisition and do in fact reflect a market of sorts for pipeline rights of way. The Board feels, however, that individual, isolated deals negotiated should not be accorded much weight unless the circumstances relative thereto are fully known, since extenuating circumstances could result in such payments having been unreasonably high or unreasonably low."

With respect, I think this statement is correct. The board is not bound to set compensation at the same amount as is of fered by the oil company, for there may be reasons for the companies of fering higher prices than they think they are bound to pay; it is a matter to be weighed by the board. However, where there are such a number of deals established so that it may be said that a pattern has been established by negotiations between the landowners and oil companies in a district, then the board should depart from such compensation only with the most cogent reasons. I think it should be accepted that no matter how expert outsiders are, the oil companies and landowners have the better judgment as to what compensation should be paid in their own interests.

The Court stated the principles that governed the case without reference to the previous decisions, except for the earlier Surface Rights Board decision that it quoted. The principles are clearly stated, except that in the Court's own words the pattern of dealings evidence (if it meets

19. Id. at 489. 
certain standards) should be departed from only with the most cogent reasons, while, in the words of the Board decision 73/37 E, being words that the Court held to be a correct statement, the pattern of dealings evidence was only to be used in the absence of evidence of market value of land. It seems correct to prefer McDermid J.A.'s own words over the words that he quotes. Nevertheless, the point has recurred in later Queen's Bench cases.

Subsequent judgments in the Court of Appeal, all delivered by Stevenson J.A., have referred back to Livingston v. Siebens as the leading case on the pattern of dealings issue. The first such case was Whitehouse v. Sun Oil Co. ${ }^{20}$ in September 1982, being a review of the annual compensation payable under a surface lease. For reasons not relevant at this point, the compensation decision of the Board could not stand, nor could that of the Court of Queen's Bench. Assessing compensation itself, the Court of Appeal followed the Board's practice of dividing annual compensation into two components, namely, loss of use and adverse effect. Fixing the loss of use, the Court initially put aside any conclusions that might be drawn from other lease rental rates, and instead considered the owner's evidence about crop losses and expenses per acre, which evidence enabled it to decide on a figure. Only then did it turn to the evidence of other lease payments: ${ }^{21}$
Assuming that the evidence relating to other leases did meet the stringent test for the ad- missibility of this kind of evidence laid down in the decision of this court in Livingston v. Siebens Oil \& Gas Ltd., it suffers from the serious defect that adverse effect on sur- rounding land was a feature in determining those payments. In the absence of evidence enabling the court to isolate that element, these figures could only assist in evaluating the total annual award for both factors, if the takings were comparable. One witness did try to make this breakdown but his figure for damage to surrounding property was clearly not accepted by the Queen's Bench Judge. Here the overall average would come close to the award which we propose making.

Thus, Livingston v. Siebens was taken as laying down a test for what sort of pattern of dealings evidence could be accepted. Yet although in Livingston v. Siebens the Court was entirely content to rely on leases that did not break compensation down into components, in Whitehouse $\mathrm{v}$. Sun Oil it was not prepared to do so. If the pattern evidence did not break the total annual award down into components, then it was of no use when the Court was fixing compensation for individual components, except as a confirmation of the end award. The Court was plainly unwilling to make a global award in order to circumvent this difficulty.

It was only two months before Livingston v. Siebens was again considered by the Court of Appeal, in Petryshen v. Nova. ${ }^{22}$ The Surface Rights Board had rejected the evidence of a number of agreements between farmers in the area on the one hand, and Nova and two other pipeline companies on the other, all for compensation at $\$ 950$ per acre plus further sums for damage to the land. When the case went to the

20. [1982] 6 W.W.R. 289.

21. Id. at 297.

22. (1982) 27 L.C.R. 276 (Alta. Q.B., C.A.). 
Court of Appeal, it was again Stevenson J.A. who delivered the judgment: 23

This appeal falls to be decided on a narrow ground in the circumstances. Paraphrasing McDermid J.A. in Siebens Oil \& Gas Ltd. v. Livingston the board was not bound to set compensation in the amount agreed to by others negotiating compensation for similar holdings, but where, as here, a pattern has been established the board should depart from that pattern only with cogent reasons. No reasons for departing from that pattern were put forward by the board and in that situation Bracco J. was fully entitled - if not obliged - to interfere. In these circumstances the board erred in fixing the compensation. If the board rejected that evidence it was obliged, in our view, to express its reasons in order to comply with the strictures expressed by McDermid J.A.

Petryshen v. Nova therefore followed and applied Livingston v. Siebens without qualification. Whitehouse v. Sun Oil was not referred to, even though there seems to have been potential for the problems of that case to be raised. ${ }^{24}$ Stevenson J.A. went on to point out that the operator should not have a reduction for residual and reversionary values. An award based on compensation for comparable transactions already takes residuary and reversionary values into account, because the figure is compensation for all but those items excluded under the agreement.

The third Court of Appeal case is Nova v. Bain, ${ }^{25}$ an oral decision given in January 1985. The Board had relied on cogent evidence of a pattern of dealings, following Livingston v. Siebens, and it was the operator who appealed to the Queen's Bench. The Board's awards were upheld by Holmes J. after a full discussion. ${ }^{26}$ He held that the Board had made no manifest error in attaching considerable weight to the evidence of comparable settlements negotiated by two other operators in the district, Canadian Hunter and Peace Pipe Lines. On the operator's further appeal, the Court of Appeal restated the general principle through Stevenson J.A.:27

It is clear from authorities in this court, most recently our decision in Petryshen v. Nova that if the Board, or on an appeal, the court, finds a pattern established it not only should apply the results of that pattern, it should not depart from it without having good reason for doing so.

This the operator sought to avoid by calling evidence to show that the comparable settlements establishing a pattern were made under undue pressure of time and were not freely negotiated. This evidence of an extraneous factor affecting the amounts paid did not persuade the Board or Holmes J. who said:28

The evidence of a pattern of freely negotiated pipeline right-of-way settlements in the same general area during approximately the same time frame was simply overwhelming, in this court's view.

23. Id. at 282.

24. Whitehouse concerned annual payments, and the difficulty was that the pattern of dealings evidence did not distinguish between the two components that made up an annual payment, loss of use and adverse effect. Petryshen, however, concerned first year payments. (Being a pipeline right of way, it involved no award of an annual payment.) The pattern of dealings evidence again appears not to have distinguished between the different components, but the Court appears to have accepted it as setting a compensation level for all losses except the landowner's time spent on the proceedings, and damages. See supra n. 22 at 280, 282.

25. Unreported, 11 January 1985, J.D. of Edmonton, 17757 (Alta. C.A.).

26. Nova v. Bain (1984) 33 Alta. L.R.(2d) 187 (Q.B.).

27. Supran. 25.

28. Supra n. 26 at 190. 
The Court of Appeal refused to interfere. This evidence had been expressly rejected, and the trial judge had not been guilty of ignoring other evidence which could have been said to weaken the pattern. "We, as an appeal court, are precluded from retrying cases. At root that is what we are being asked to do."

Another point taken by the operator was that some compensation factors had been dealt with in damage releases and were not reflected in the pattern agreements. The pattern could only be applied if the agreements embraced the same factors. However, when inspected, the documents did not bear out that contention. The releases related not to compensation for the taking and the effects of the taking, but for damages arising from operations.

Before we proceed to consider the Queen's Bench decisions, it will be convenient to state just what seems to be the gist of the Court of Appeal judgments. The type of evidence in question is evidence of a course or pattern established in the dealings between landowners and oil companies; the dealings must be negotiated or agreed to; and they must be in the one area or district. If the evidence meets these requirements, then it is very weighty evidence. Although the Board is not bound to follow such evidence, it can depart from it only by giving cogent reasons. Individual isolated cases can be given very little weight. Care must be taken to ensure that the items for which compensation was being agreed on in the transactions in evidence are the same as the items that the Board or court is fixing compensation for.

Of the Queen's Bench decisions, Eastman v. PanCanadian Petroleum Ltd. ${ }^{29}$ was decided before Whitehouse v. Sun Oil and Petryshen v. Nova and after Livingston v. Siebens, even though it did not refer to it by name. MacLean J. had before him evidence of land values from the operator's expert, but found that it was unreliable and uncertain. Instead, the owner's evidence of the rates being paid by the operator and by other companies for pipeline rights of way on comparable lands in the same period satisfied the learned judge that "there was a pattern or a standard rate of compensation that was being paid to the land owners in the area". Given the unreliability of the valuation evidence, the evidence of the pattern or standard rate of compensation was the best available evidence, and it deserved very great weight. The evidence included fourteen oil companies and twelve to fifteen landowners. An objection that much of this evidence related substantially to one landowner, the Eastern Irrigation District, could not be sustained, particularly as the number of acres controlled by all the landowners as a whole was very great.

At the Court of Queen's Bench level in Petryshen v. Nova, ${ }^{30}$ before the case went to the Court of Appeal, Bracco J. quoted Livingston v. Siebens and applied it to the pattern evidence heard by the Board and then by him: ${ }^{31}$

Clearly it was an error for the board to ignore such cogent and weighty evidence and embark on the very uncertain task of attempting to identify and evaluate the numerous

29. Unreported, 5 March 1982, J.D. of Medicine Hat, 8208-00170 (Alta. Q.B.) per MacLean J.

30. Supra n. 22.

31. Id. at 278. 
factors that must be considered to determine a just compensation. Such a procedure is appropriate when there is no evidence of comparable agreements reached for identical benefits between willing sellers and willing buyers where the parties, the land, the subject-matter of the agreement and the timing are all comparable and applicable.

Shortly afterwards, Livingston v. Siebens was quoted again, in Hudson's Bay Oil and Gas Co. Ltd. v. Dau, but what was extracted from the leading case was that "evidence of negotiated settlements may be considered by the board and this court but such settlements must be weighed in the light of other relevant evidence."'32 The view so expressed was put into practice by attaching no weight to the pattern evidence that was given by the president of the local surface rights group. Pattern evidence was seen to be no more than equal to any other sort of evidence, in marked contrast to the priority of place accorded to it by the Court of Appeal in Livingston v. Siebens and, subsequently, in Petryshen v. Nova.

The next cases adhered much more closely to the view that if there is evidence that establishes a pattern, then that is the evidence that must be followed: ${ }^{33}$

\begin{abstract}
If a pattern for voluntary agreements between other landowners is established and that pattern is within an acceptable area and involves similar land, then, in my opinion, no more cogent form of evidence could be used to assist the board and this court in arriving at an amount of compensation. That proposition was amply stated by Bracco $\mathrm{J}$. in Petryshen v. Nova...
\end{abstract}

This was said by Decore J. in Markovich Bros. Farming Co. Ltd. v. PanCanadian Petroleum Ltd., who then ruled that the Board had made a weighty error in not making a decision similar to eight agreements made by one operator with other landowners, even though some of the land involved was twenty or thirty miles distant. However, in Haukedal v. Dome Petroleum Ltd., ${ }^{34}$ only one voluntary agreement for similar surface rights was tendered, and Decore J. had no difficulty in finding that it did not establish any pattern or give any grounds for upsetting the Board's decision. In Nova v. Bain, ${ }^{35}$ Holmes $\mathrm{J}$. followed the same authorities to find the existence of a pattern of freely negotiated agreements, notwithstanding the suggestion that the agreements were tainted by undue pressure on the operators, a decision that the Court of Appeal left undisturbed. ${ }^{36}$ Golden Eagle Oil and Gas Ltd. v. Carlstad, ${ }^{37}$ the next case, was deferred until the Court of Appeal had dealt with Bain's case, which Dixon J. then followed as fully confirming the adoption of pattern of dealings evidence, or "area agreement or global approach" as he called it. However, the evidence was deficient. Of the 125 agreements, twenty-three Board decisions and one court case that were put in to establish a pattern, only four or five were within twenty-five miles of the site in question: ${ }^{38}$

32. (1982) 25 L.C.R. 243 at 249 (Alta. Q.B.).

33. Markovich Bros. Farming Co. Ltd. v. PanCanadian Petroleum Ltd. [1984] 3 W.W.R. 416 at 420 . (Leave to appeal to C.A. denied).

34. [1984] 3 W.W.R. 422.

35. Supran. 26.

36. Supran. 25.

37. Unreported, 30 January 1985, J.D. of Peace River, 84090141 (Alta. Q.B.) per Dixon J.

38. Id. at 8 . 


\begin{abstract}
It is clear to me that on the basis of lack of proximity alone that the correct decision is that the area agreement or global approach evaluation should not be adopted on this appeal. In addition, I must make the observation that Exhibit $\# 13$ did not contain the details of the acreages involved, the agricultural classification of the lands involved, and the effective dates of the various agreements and decisions and had I appreciated that these deficiencies existed at the time of the appeal I would not have accepted this document as an exhibit.
\end{abstract}

In finding that no pattern was established, Dixon J. was following the Board's decision.

Reference may also be made to three brief judgments which have some bearing on pattern of dealings evidence, but which do not make any direct reference to the leading cases. In Arthur v. Dome Petroleum Ltd., ${ }^{39}$ a surface lease rent review was based on the amount recently agreed to between the same parties for two other leases on the same quarter section of land. In Westmin Resources Ltd. v. Brodbin, ${ }^{40}$ the Court accepted the Board's use of the operator's of fer to the owner as its starting point only because the offer was in keeping with some sixty other leases negotiated. Finally, in Walde v. Great Basins Petroleum Ltd. ${ }^{41}$ MacLean J. (who had also decided Eastman v. PanCanadian Petroleum Co. $L t d$.) accepted the pragmatic approach of the Board and its skill and experience, and refused to upset a Board decision which had found the pattern of dealings evidence to be inadequate and had relied on other evidence and reasoning to fix compensation.

By clarifying the criteria for judging pattern evidence, these Queen's Bench decisions have contributed to the development of the pattern of dealings approach. The agreement tendered in evidence must be comparable with the case in issue in terms of the rights granted, the type or classification of the land, proximity, date, acreage and the type of parties. And one agreement does not make a pattern. However, some of these cases have not advanced our knowledge of how to use pattern evidence once a pattern has been found; Hudson's Bay Oil and Gas Ltd. v. $\mathrm{Dau}^{42}$ is incorrectly decided in giving too little weight to the pattern evidence. And Bracco J., in Petryshen, ${ }^{43}$ in saying that one can consider other evidence only if there is no evidence of comparable agreements, appears to give pattern evidence even more weight than the Court of Appeal envisages when it allows a departure from pattern evidence on the basis of cogent reasons.

This case law on pattern of dealings evidence has certainly had a profound effect on the practice of the Surface Rights Board, but, as a few examples will illustrate, the result has been one of diversity rather than uniformity. Because many cases see the parties taking vigorously opposing views on the correct approach, the Board often seems to be pulled in different directions. Its decisions consequently appear to be made on the basis of the evidence and arguments put forward in each individual case, rather than on the strength of any unvarying policy on the subject. In

39. Unreported, 2 May 1984, J.D. of Vegreville, 8311-00256 (Alta. Q.B.) per Dechene J.

40. Unreported, 18 December, 1984, J.D. of Vegreville, $8411-0018$ (Alta. Q.B.) per Smith J.

41. Unreported, J.D. of Medicine Hat, 8308-001730 (Alta. Q.B.) per MacLean J.; on appeal from Board Decision C84/83.

42. Supran. 32.

43. Supran. 30. 
Dome Petroleum Ltd. v. Oatway, ${ }^{44}$ the Board expressed some irritation at how the parties had muddied the waters espousing very adversary positions on the correct approach to awarding compensation. But if a pattern of dealings approach is not advocated, the Board may use the four heads approach. ${ }^{45}$ On the other hand, the Board frequently uses the pattern of dealings approach to fix compensation, not only where it is strongly advocated in the face of opposition from the operator, ${ }^{46}$ but also as a matter of routine in more straightforward cases. ${ }^{47}$

A number of very different statements are to be found in Board decisions about the effect, or weight, to be given to pattern of dealings evidence. (Lest this be thought to be an uncharitable criticism of the Board, it is only proper to bear in mind the wide diversity of opinions that the courts have offered on the subject.) In some decisions, evidence of privately-negotiated agreements is regarded as no more than a back-up if other evidence is not available: ${ }^{48}$

The Board is always in a position to turn to the principles of Siebens v. Livingston in the event no cogent evidence of land values and other aspects of compensation under section 25 of the Act is presented.

In other decisions, the legislation itself is seen as the mere back-up to pattern of dealings evidence, "to provide a means of settling compensation in circumstances which don't fit with any pattern of dealings in effect at the time." 49 Livingston v. Siebens ${ }^{50}$ is sometimes seen as being an alternative to the Surface Rights Act which gives the Board its jurisdiction. ${ }^{51}$ Taking a middle course, the Board has said on occasion that it would neither accept nor reject the pattern evidence in total. ${ }^{52}$ In some cases the pattern of dealings approach is transmuted into the "equity approach", wherein a landowner should receive what others are receiving in his area with specific consideration given to his land use. ${ }^{53}$

Even in cases where there has been no question about the weight to be given to suitable pattern of dealings evidence, the Board considers carefully whether the evidence does in fact establish the existence of a pattern of negotiated dealings. There are many decisions in which the Board has found the pattern evidence to be inadequate and has therefore used the four heads approach instead..$^{54}$ In other cases, the Board has re-

44. Supran. 6.

45. E.g., Cimarron Petroleum Ltd.v. Kuzubski, S.R.B. Decision E214/84.

46. E.g., Nova v. Sawchuk, S.R.B. Decision E242/84.

47. E.g., Geocrude Energy Inc. v. Doll, S.R.B. Decision E241/84.

48. Tai Resources Ltd. v. Collins, S.R.B. Decision C63/83.

49. Nova v. Harding, S.R.B. Decision 245/84.

50. Supran. 5.

51. E.g., Aries Resources Ltd. v. The Queen and Majestic Ranches Ltd., S.R.B. Decision C66/83.

52. PanCanadian Petroleum Ltd.v. Mullen, S.R.B. Decision C74/81.

53. Husky Oil Operations Ltd.v. Tondu, S.R.B. Decision E200/84.

54. Dekalb Petroleum Corp'n. v. Drysdale, S.R.B. Decision E201/84 (little relationship between lands); Shell Canada Ltd. v. Wabash Industries Lid., S.R.B. Decision E202/84 (different land use and potential); Gulf Canada Resources Inc. v. The Queen and Gering, S.R.B. Decision E215/84 (no pattern in the evidence); Westburne Petroleum \& Minerals Ltd. v. Wiebe, S.R.B. Decision C30/84 (no pattern for similar lands in similar use). 
jected the pattern evidence submitted by the owner and instead used data on agreements received in other hearings in the area. ${ }^{55}$

The legal authority for the use of pattern of dealings evidence has been made quite plain at all levels. Taking their lead from Livingston v. Siebens, the courts and the Board have developed a clear test for the acceptability of evidence to establish a pattern of voluntary dealings. The analysis of what is acceptable continues as agreements are increasingly scrutinized for similarity with the land in issue and for the circumstances in which they were concluded. This carefulness is very like the attention given to "comparable sales" used by appraisers to find the market value of land, and indeed the two processes are not all that different from each other. It should of course be borne in mind that this judicial approval of pattern evidence does not necessarily extend to the global or lump sum awards that have yet to be considered as a separate issue.

As for the weight to be given to pattern of dealings evidence, the legal position is established with the Court of Appeal's pronouncement on two occasions that it is evidence that should be departed from only with cogent reasons. But even in Livingston v. Siebens, there were words that would allow evidence of market value of the land to prevail over evidence of a pattern of negotiated dealings, a tack that was followed in Hudson's Bay Oil and Gas Co. Ltd. v. Dau. ${ }^{56}$ It is revealing to learn that the same point is completely unresolved in expropriation law. Some cases and authorities have altogether ruled out evidence of settlements or awards made in other expropriations with a view to avoiding litigation, while others have allowed such evidence to be used with great care and circumspection. ${ }^{57}$

Whether or not it is legitimate to base a pattern on previous Board decisions or court decisions, as well as on surface leases and right-of-way agreements, has not yet been faced squarely in the courts. Previous Board decisions have been submitted as evidence in several of the cases that we have considered, Golden Eagle Oil and Gas Ltd. v. Carlstad ${ }^{58}$ for one. However neither Livingston v. Siebens nor any of the other leading cases have ever approved a "pattern of decisions". The emphasis has always been on the judgment of oil companies and landowners in their own interests, and on free negotiations. If the Board accepts as evidence what it awarded on some previous occasion, it is not obtaining information from any outside source; it is listening to itself. Its award on the previous occasion may have been too high or too low. The case is quite different from the Board making reference to evidence that it heard in a previous hearing, or taking notice of information in a way that a court could not. It is also quite different from the Board making a policy decision to maintain some uniformity in awards. The introduction of evidence of previous decisions made by the Board or by the courts should

55. Thomson-Jensen Petroleums Ltd. v. Stoner, S.R.B. Decision E291/84.

56. Supran. 32.

57. E. Todd, The Law of Expropriation and Compensation in Canada (1976) 161; Budd v. Minister of Transportation (1979) 25 N.B.R. (2d) 682 (N.B.S.C. App. Div.).

58. Supran. 37. 
therefore be rejected as an attempt to lift oneself up by one's own bootstraps.

One of the noteworthy effects of the pattern of dealings approach has been to circumvent the difficulties of the residual and reversionary values argument. As Petryshen v. Nova pointed out, we can readily assume that the comparable transactions took those values into account. It may also be observed that although Caswell v. Alexandra Petroleums Ltd. ${ }^{59}$ and Lamb v. Canadian Reserve Oil and Gas $L t d .{ }^{60}$ are almost always given a ritualistic mention, the courts have shown little deference to the knowledge and expertise of the Surface Rights Board, and have been all too willing to disturb its decisions on the use of pattern of dealings evidence. This willingness is increasingly at odds with the general trend of administrative law principles. ${ }^{61}$

\section{USEFULNESS OF THE PATTERN OF DEALINGS APPROACH}

Having thus far considered the pattern of dealings approach entirely in terms of its legal validity, we can touch, even if only briefly, on the broader questions of the ef fectiveness of the approach as a method of fixing compensation. It is easy to agree with the higher courts that pattern of dealings evidence is very convincing. It has to be scrutinized from various points of view to ensure that its components are comparable and that they indeed do form a pattern, but once a pattern is established, it provides a powerful instrument with which to ascertain proper levels of compensation.

However, there is room for an extended debate about the validity of pattern evidence as a matter of economic theory. The "market of sorts" in which surface leases and right of way agreements are negotiated is a very imperfect market. The rights being traded are dependent on the Surface Rights Act. It is dominated by the compulsory powers of the Surface Rights Board. Each party knows that Board proceedings are always an alternative, and his goals in negotiating are strongly influenced, if not dictated, by his estimation of what the Board would award. The costs and the time required for Board proceedings, compared with negotiation, are also an important influence. In deciding how high he is prepared to go in his negotiations, the operator takes account of the higher legal and expert costs he will have to pay not only for himself but also, inevitably, for the owner. The costs of delay also weigh more heavily on the operator than on the owner, even though it is no fault of the owner that the operator of ten leaves it until the last minute to fulfill drilling obligations or to finalize land acquisition for a pipeline. If the Board, for its part, is strongly influenced by the figures set in such negotiations, a cyclical effect emerges. Although the results of this effect may be difficult to predict, the need for caution is plain to see.

We have reviewed a number of cases where pattern evidence seems to have worked very well. There are other cases where other evidence has

59. Supran. 4.

60. Supran. 3.

61. E.g., Alberta Union of Provincial Employees v. Olds College [1982] I S.C.R. 923. 
worked well to calculate compensation, and sometimes even better. For example in Walde v. Great Basins Petroleum Ltd., ${ }^{62}$ there was pattern of dealings evidence, but the Board found that it was inadequate, especially in the light of the other evidence available, which was a more immediate indication of the annual impacts of the operation on the landowners. The loss of use could be calculated accurately enough by referring to the carrying capacity of the land. The only other real imposition on the landowner was a need to inspect his cattle more frequently around the wellsite and access road. Once an hourly rate for an unskilled worker with a vehicle could be arrived at, the cost of the extra imposition on the landowner could be quantified with ease.

The main point that stands out is that to carry out the difficult work of fixing compensation, the Board should be able to use all available tools, with the minimum of fixed rules about their selection. It should be possible to embark upon an individual case with an open mind about which method will be the best for fixing compensation. There should be a minimum of prescriptions and proscriptions limiting the inquiry. No single method can claim a monopoly on accuracy. Such an eclectic attitude would acknowledge that neither the value of the land, nor the four heads approach, nor the pattern approach will always be better than any other source of information, and that, on occasion, useful information may be obtained from more than one of them. To put it another way, the "great weight" to be given to pattern evidence is not so leaden as to crush the useful life out of all other evidence. The "cogent reasons" for which Livingston v. Siebens allows a departure from pattern evidence should include the finding that another approach is demonstrably and logically better at fixing compensation in the particular case.

\section{GLOBAL AWARDS}

The global award, which we earlier distinguished from pattern of dealings evidence, but which is closely connected to it, makes an appearance in several of the cases considered above. However, most of the Court of Appeal cases have little to say on the subject. The report of Great Plains Development Co. of Canada Ltd. v. Lyka ${ }^{63}$ discloses nothing about global awards. In Livingston v. Siebens, the Appellate Division affirmed a judgment that had awarded compensation under each of the four heads, but without any discussion of the correctness of doing so. ${ }^{64} \mathrm{In}$ both Petryshen v. Nova ${ }^{65}$ and Nova v. Bain ${ }^{66}$ the awards were global ones, but again in neither case did the Court of Appeal comment on the

62. Supra n. 41.

63. Supran. 13.

64. Supra n. 13. Although in Livingston, at 490 , McDermid J.A. criticizes the lower court's action of splitting up the amount of $\$ 1,600$ (found through the pattern evidence) amongst the board's four heads, it is plain that the criticism is not aimed at the actual splitting up of the amount. It is aimed at the simple adoption of the company's offer (which was so split up) rather than starting with the board's award and considering how the new evidence would have affected it.

65. Supran. 22.

66. Supran. 25. 
subject. In these cases, then, the validity of global awards is a point that at best passed sub silentio.

Global awards did figure significantly in Whitehouse v. Sun Oil Co., ${ }^{67}$ though not described by that name. It will be recalled that the evidence of a pattern of dealings did not break the annual compensation down into components; but in the Court of Appeal's view compensation in this case did involve two primary components, namely, the value of the loss of use, and the adverse effect on surrounding lands. The pattern evidence suffered from a "serious defect" in not isolating the two elements. Other evidence was used in order to avoid making an award that covered both elements in one sum. It could be argued that global awards were not fully canvassed and that therefore little weight can be given to this part of the decision; but a review of the case as a whole makes it clear that the possibility of making a global award was ruled out by the Court as a step in reaching its decision. The earlier part of the judgment deals in detail with the obligations of the Surface Rights Board in making its awards. The Board is obliged by statute to give reasons, ${ }^{68}$ and if it does not set out the evidence and the processes of reasoning that it used, bearing in mind the views of the Supreme Court of Canada in Northwestern Utilities Ltd. v. Edmonton, ${ }^{69}$ then a judge on appeal will not be able to identify how the Board used its expertise, and the award will not be entitled to weight under the rule in Caswell v. Alexandra Petroleums Ltd. ${ }^{70}$ and Lamb v. Canadian Reserve Oil and Gas Ltd. ${ }^{71}$ The Court was therefore careful to ensure that its own reasoning processes were revealed, and separate consideration of the two components in the compensation was necessary in order to do so.

Eastman v. PanCanadian Petroleum Ltd. ${ }^{72}$ was the first case in which global awards were referred to under that name. It was a case where the reasons for judgment were delivered orally, but the frequent reliance that is placed upon it justifies a close review. Having decided (as previously described) that the pattern of dealings evidence was more cogent than anything before the Board, and that the pattern indicated compensation of $\$ 600$ per acre, MacLean J. said:

It is difficult to split that figure and allot it in various proportions. The practice both in the Surface Rights decisions and in the decisions of this Court, has been to allocate specific amounts to the various factors set out in section 23(2) [now s. 25] of the Surface Rights Act, but allocation, in my mind, is not necessarily required under the Act. All that is required is that the Court consider the various factors that are set out under that Act.

I am satisfied that the evidence in this particular case supports the fact or supports the proposition that it is the total figure, the end figure, that is important not just to the oil company operator, but to the landowner as well; and that the breakdown of the figure is a matter that the landowner is perfectly prepared to leave to the discretion of the operator oil company. I would think that the reasonable inference that should be drawn from that kind of an approach is that the oil company, the operators at least, are aware

67. Supran. 20.

68. Administrative Procedures Act, R.S.A. 1980, c. A-2, s. 7.

69. [1969] I S.C.R. 684.

70. Supran. 4.

71. Supran. 3.

72. Supran. 29. 
of the factors to be considered and have considered them in arriving at the global lump sum, a single figure; and the farmer-owner, on the other hand, although he might not be aware of the particular provisions of the Act, is aware of the kind of things that he should address his mind to so that he can arrive at his overall compensation. Again, that is the end figure that they are both interested in.

Certainly, the end figure is the centre of interest when the cheque is being written; but these observations do not give us any guidance about how to arrive at that figure. Nor is it very clear what significance lies in the different interests that the operator and the farmer-owner may be thought to have in the breakdown.

It is important to note that MacLean $\mathrm{J}$. did not fail to reveal his reasoning in relation to the evidence:

\footnotetext{
In arriving at that amount, 1 have been guided by the headings of compensation that are set out in the Act under Section 23 Subsection 2, and in particular, 1 have been guided by the headings, or manner in which damages were allocated in paragraph four of Exhibit 6, which is the respondent's letter agreement recording an agreement reached on the 11 th of March - setting for the rates for 1980, and those headings are, value or consideration for the land at $\$ 450.00$ an acre, prepaid damages at $\$ 100.00$ an acre, and $\$ 50.00$ an acre for regrassing and repair that may be necessary after the initial reclamation. Now, I have said that $I$ used those things as guides, but in this judgment as in the case as demonstrated by the evidence, I have arrived at my figure having considered all of the factors without breaking them down into any headings. I simply break them down to give some indication as to what my thinking was in relation to the evidence.
}

This breakdown is not the same as the conventional "four heads" breakdown, and the learned Judge only of fers it as an indication as to his thinking; but it is most noteworthy to find it given here at all in this judgment that is so often cited as the best expression of the global approach.

The next case, Dome Petroleum Ltd. v. Grekul, 73 came out firmly against global awards. The Board had made an award under unusual headings - severance, inconvenience and damage done to the demised premises; rental; incidental damages; and costs. The primary challenge to the Board's award was that it had failed to give adequate reasons. Miller $\mathrm{J}$. analyzed the question in detail. He considered s. 7 of the Administrative Procedures Act, ${ }^{74}$ which requires the Surface Rights Board to give "the findings of fact on which it based its decision, and the reasons for the decision" in writing. He quoted Whitehouse v. Sun Oil 75 for the obligation of the Board to reveal its reasoning processes, and to do more than merely recite the fact that the evidence and arguments of the parties have been considered. He then scrutinized the Board's decision in this case to see what steps the Board had taken in reaching its conclusions. In order to say what level of detail in reasoning was required to comply with the Administrative Procedures Act and the guidelines in the decided cases, it was useful to consider the underlying purpose of the Surface Rights Act. Its purpose, he said, is to provide the landowner and the operator with a quick and relatively inexpensive way of getting an independent appraisal of the rights going to the operator and the losses suffered by the landowner: ${ }^{76}$

\footnotetext{
73. [1984] ] W.W.R. 447 (Alta. Q.B.).

74. Supra n. 68.

75. Supran. 20.

76. Supran. 73 at 453.
} 


\begin{abstract}
Under the general framework of the Act, as I perceive it to be, the board can comply with the requirements of the Act and the Administrative Procedures Act, supra, if it clearly sets out the terms of reference under which it is making the awards, the general principles it will be applying, makes the necessary findings of fact where there is conflicting evidence and breaks the award down under generally accepted heads of damages. In my view, it is not necessary for the board to provide a detailed listing of the actual calculations it has used to come to its conclusions. This is no different from the requirement placed upon a judge of this court. He or she must give reasons for coming to his or her conclusions, but 1 know of no requirement to provide a breakdown of every calculation that leads to a damage award. I am unable to see why a different standard should be imposed upon the board.

With these general principles in mind, I have again reviewed the board's decision in this case. The only aspect of the decision which gives me concern is the lumping together of three heads of damages under one "global" amount. I refer specifically to the award of $\$ 3,700$ for "severance, inconvenience and damage done to the demised premises as a result of the right of entry for the first year". It would be impossible for an appeal authority to determine with any accuracy what portion of the $\$ 3,700$ the board allotted for severance, inconvenience or damage.
\end{abstract}

Miller J. continued by bringing to bear the principles being laid down by the courts in the more general field of law beyond surface rights. He applied the Alberta Court of Appeal and Supreme Court of Canada decisions in Andrews v. Grand \& Toy Alberta Ltd. 77 These decisions had concluded that a global award of general damages is not as sound as an assessment of damages under separate headings. The parties are entitled to know what sum is assessed for each relevant head of damage, to be able to challenge any error on appeal, and to assure themselves that each head has been given thoughtful consideration. It is also the only way that the award can afford reasonable guidance in future cases. Miller J. held that these principles applied to surface rights practice: ${ }^{78}$

Section 23(2) [now s. 25(1)] of the Act specifically breaks down the areas which the board may consider in arriving at its award of damages for the "taking" by the operator. Section $23(2)(b)$ refers to the severance, s. 23(2)(c) refers to the inconvenience, s. $23(2)(d)$ refers to the damages caused by the operator's use of land and s. $23(2)(e)$ refers to other factors that the board considers proper under the circumstances.

In my view, the lumping together of these four heads of damages into one global award of fends the principles set down in Andrews case, supra, and is a practice that should be discouraged. The practical effect of the board's treatment of this aspect of their decision in the case at bar is that I cannot accord the board's expertise much weight in arriving at my decision in this appeal on those heads of damage.

Given that the conclusion that global awards are unsound is certainly the result of a thorough analysis of the Surface Rights Act and of several different threads of legal principle, Dome v. Grekul is a judgment that deserves substantial respect.

Markovich Bros. Farming Co. Ltd. v. PanCanadian Petroleum Ltd. ${ }^{79}$ followed five months later and is the clearest exposition of the opposite point of view. To Decore $\mathrm{J}$., the issue was simply whether the "global approach" or the "four heads approach" should be used. The four heads approach was described as a method used by landmen and the Board, looking at the factors mentioned in the Act for compensation, but overstressing the value of land, failing to look at other methods which

77. [1978] 2 S.C.R. 229, reversing in part [1976] 2 W.W.R. 385.

78. Supran. 73 at 455 .

79. Supran. 33. 
[VOL. XXIV, NO. 1

may amount to more cogent evidence and failing to consider the other factors that may be involved. In contrast: ${ }^{80}$

The global approach is the method advocated by the appellant in this instance. It is a system that looks at many factors that must be considered, all of them interrelated, when determining an award. Perhaps its most important feature is that it acknowledges that the split figures suggested in the four heads approach may be too artificially arbitrary. Perhaps the best expression of the approach is contained in Eastman v. PanCanadian Petroleum.

Decore J. quoted from Eastman v. PanCanadian, setting out the first passage quoted above, ${ }^{81}$ but omitting the second, in which MacLean $\mathrm{J}$. had given an indication of the relation of his figure of $\$ 600$ per acre to different aspects of the evidence. Decore J. continued: $:^{82}$

Which method ought to have been followed by the board in this instance? In my opinion, the global approach is the better method, provided some sort of cogent evidence can be produced that would allow its application. In my opinion, the strongest and most cogent evidence under which the global approach would be of assistance is evidence that shows what other voluntary agreements have been entered into in the area. If a pattern for voluntary agreements between other landowners is established and that pattern is within an acceptable area and involves similar land, then, in my opinion, no more cogent form of evidence could be used to assist the board and this court in arriving at an amount of compensation. That proposition was amply stated by Bracco J. in Petryshen v. Nova.

The connection was thus made between the global approach and pattern of dealings evidence. Decore J. used that type of evidence to fix compensation in one sum for the first year and another for each year thereafter. A company landman who stuck to the four heads approach was branded as "stubbornly unyielding" for refusing to admit that another method could be used. PanCanadian was denied leave to appeal the decision to the Court of Appeal.

Nova v. Bain ${ }^{83}$ focussed on the use of pattern of dealings evidence rather than on the global awards issue. The figure of $\$ 950$ per acre that was found in many of the negotiated agreements obviously included adverse effect, general disturbance, nuisance and inconvenience as well as the value of the interest taken, and so did the Board's award, which Holmes J. and then the Court of Appeal declined to interfere with. Holmes J. said of the Board: 84

It preferred to make an inclusive or global award since separate compensation under each of those heads is very difficult, if not impossible, to quantify with any degree of precision. Presumably, the board has developed some expertise assessing such intangible factors and some degree of uniformity although not mandatory, is desirable.

Golden Eagle Oil and Gas Ltd. v. Carlstad ${ }^{85}$ also needs to be mentioned in respect of global awards. Dixon J. took Nova v. Bain to confirm the global approach, but of course the Court of Appeal had not used that phrase and had not dealt with the validity of lump-sum awards at all. The Board in Golden Eagle had made lump-sum awards of $\$ 8,000$ for the first year and $\$ 2,000$ per annum thereafter. It had rejected all the evidence before it and virtually the only reason it gave for its awards was "its

80. Id. at 419.

81. Supran. 72.

82. Supra n. 33 at 419.

83. Supra n. 25 and 26.

84. Supra n. 26 at 192.

85. Supra n. 37. 
knowledge gained through numerous involvements in similar situations". Dixon J. held that the Board decision should not be set aside as it had given sufficient reasons and "detailed findings of fact". This is a startling conclusion, all the more so when one considers that the Board decision so approved is even more scanty than the decisions that were found wanting in Whitehouse v. Sun Oil Co. ${ }^{86}$ and Chieftain Development Co. Ltd. v. Lachowich, ${ }^{87}$ which Dixon J. quoted at length, and Dome v. Grekul ${ }^{88}$ and Transalta Utilities Corporation v. Olson, ${ }^{89}$ which he did not quote at all. ${ }^{90}$

Transalta v. Olson was another case applying Whitehouse v. Sun Oil and Dome v. Grekul to a Board award which had not given specific reasons for one component of the compensation. The award was held to be deficient in this regard. Another minor case is Walde v. Great Basins Petroleum Ltd., ${ }^{91}$ where the Court refused to interfere with a Board award under different heads. MacLean J. was critical of people who simply say, "Let's pay these kind decent hardworking landowners this rate and let's not worry about inconvenience or adverse effect or what the residual or other rights are, let's do it on this formula." 92

As for the Surface Rights Board, its practice is almost without exception to make a global award where it uses pattern of dealings evidence, but not otherwise. The Board often indicates that it believes that the global approach is required by the Surface Rights Act. In Wintershall Oil of Canada Ltd. v. Congregation of the Most Holy Redeemer the Board said: 93

With respect, it is the Board's opinion that what the Act says (at section 25 and in total context), and says very clearly and unequivocally, is that in determining compensation an all-inclusive, all-encompassing (or to use the coined expression "global") consideration shall be given to the total ef fect of the right of entry on the rights of the landowner. As some of these effects are or may be of largely intangible nature which is difficult to measure other than judgmentally or conjecturally, the process of attaching dollar sums individually to each tends to become a mathematical exercise, the result of which may or may not produce the necessary comprehensive consideration.

Before embarking on a discussion of the role of the global award, we may usefully distinguish between those cases where the nature of the evidence demands a global award, and those where it does not. In the former type of case, the evidence is principally evidence of a pattern of voluntary dealings, which suggests only one individual figure for firstyear compensation and one for annual compensation. An award based on such evidence must naturally do the same. To take the figure sug-

86. Supra n. 20.

87. (1981) 23 L.C.R. 298 (Alta. Q.B.).

88. Supra n. 73.

89. (1984) 31 L.C.R. 134 (Alta. Q.B.).

90. Dixon J. was annoyed at the operator for saving its better evidence up for the appeal hearing - the problem in Esso Resources v. Smulski(1981) 18 Alta. L.R. (2d) 200 (Alta. C.A.). However, he plainly expressed this to be an additional, and not a necessary, reason for not interfering with the Board's decision.

91. Supra n. 41.

92. Id.

93. SRB Decision E216/84. Similarly see Gulf Canada Resources Inc. v. Rukavina, S.R.B. Decision E15/85. 
gested by the evidence, and to split it down into a series of categories would not be justified by the evidence and would not serve any useful purpose. But what of the other type of case, where a variety of different matters are dealt with by evidence from a variety of sources? Or where there are obvious distinctions between different categories of compensable loss? Having heard such evidence, should the Board refrain from using these distinctions in its reasoning or in making its assessment? In effect, the question is whether or not we should lean towards global awards wherever possible as an inherently desirable practice.

The current legal position on the use of global awards cannot be stated with any brevity, given the mixed reactions from the courts that we have noted above, and given that the Court of Appeal has not yet ruled on the subject in as express terms as it would if it had heard the appeal in Markovich v. PanCanadian. The Court of Appeal in Whitehouse v. Sun Oil decided not to make a global award, and that decision was part of the ratio of the case, taken after a full consideration of the process of reasoning that is required of the Board. None of the other Court of Appeal cases dealt with the subject, even if some of them may be said to have resulted in one type of approach or the other. In Dome v. Grekul, Miller $\mathrm{J}$. gave the matter his express consideration, and after an analysis of the general principles and the relevant authorities, including Whitehouse, he came out strongly against global awards for a number of reasons. On the other side, Eastman v. PanCanadian endorsed the global approach, but in an oral judgment that did not refer to any precedents at all, and that gave some indication of a breakdown anyway. Markovich v. PanCanadian adopted Eastman's views, but without referring to, let alone distinguishing, Whitehouse, Grekul or any other case in point. The reasons given in Eastman and Markovich for taking the global approach were that the split figures in the four heads approach may be too artificially arbitrary, and that only the total figure, the end figure, is important.

In summary, there has been strong and authoritative criticism of the global award as a matter of law, and only scanty support can be found with which to defend it. (In this context, it should not be forgotten that throughout this analysis a distinction has been drawn between global awards and patterns of dealings evidence.) Nevertheless, there is a split of judicial opinion, and the subject is one of some controversy. It is desirable to look beyond the question of purely legal validity and consider the rationale of each of the conflicting arguments in more general terms.

In support of global awards, the rationale that is most frequently seen in Board decisions is that s. 25 of the Surface Rights Act says that consideration shall be given to the total effect of the right of entry on the rights of the owner. Wintershall Oil of Canada is an example. ${ }^{94}$ To the extent that this is an argument that no aspect should be left out, and that compensation should be nothing less than full compensation, it is unexceptionable, even if there are not actually any words to be found in s. 25 that say as much. But in going further, and suggesting that it is erroneous 
to give separate components of the total separate consideration, it is unsupported by s. 25 . The section says nothing at all about giving consideration to the total effect in one sum. Nor does the Act generally. Indeed, s. 25 points entirely in the other way. The Legislature has acted deliberately to provide a list of separate factors to guide the Board, and on occasion it has carefully amended the list. It has used expressions that clearly intend separate calculation of separate factors. For example, when it permits the Board to calculate the per acre value of the titled unit under s. 25(1)(b), or the "additional amount" necessary for a home-fora-home award under s. 25(3), the Legislature intends there to be some degree of separate analysis of separate losses and impacts.

Another reason for global awards is said to be that the split figures of the four heads approach may be too artificial and arbitrary. Even when added together they may not provide a sufficiently comprehensive view of the overall impact of the right of entry. There is considerable merit in this argument against a piecemeal approach. It is risky to assume that some pre-set grouping of issues will always be adequate. It is especially so when the "four heads" grouping, namely, value of the interest taken, general disturbance, loss of use and adverse effect, is only a convenient re-arrangement of the most frequently used factors in the Act. There is another risk if one uses a mechanistic procedure about what is and is not significant in the individual case to the exclusion of one's own judgment. However, as much as these criticisms suggest that one should abandon the four heads approach, or anything else that may be so labelled, they suggest the improvements that could be made to use that approach properly. They do not prove that it is fallacious to analyze issues independently, as long as it is recognized that the issues do interact with each other.

Support for global awards is also sought in the fact that the process of attaching dollar sums to a number of intangible effects on the landowner is merely an exercise in mathematics. Board decisions show, however, that on many occasions satisfactory evidence is available to indicate a maximum or a minimum range or even a very specific figure. Further, it is difficult to comprehend how the difficulties of applying one's judgment to the intangibles, such as nuisance, inconvenience or adverse effect, are reduced by considering them all lumped together with the more calculable effects, rather than separately.

Let us turn to the rationale on the other side. Two inter-related policies have been advanced as the rationale for discouraging global awards and for giving awards which indicate how different heads of loss have been assessed in arriving at the final figure. The first is the obligation of the Surface Rights Board to give reasons for its decisions, as Whitehouse $v$. Sun Oil ${ }^{95}$ and Dome v. Grekul ${ }^{96}$ determined. Although the common law does not impose a duty to give reasons on tribunals such as the Surface Rights Board, ${ }^{97}$ the desirability of their doing so has often been argued,

95. Supran. 20.

96. Supran. 73.

97. Re Glendenning Motorways Inc. and Royal Transportation Ltd. (1976) 59 D.L.R. (3d) 89 (Man. C.A.). 
and there has been a trend towards imposing that duty by statute. In the case of the Surface Rights Board, it was initially required in 1970 when a regulation was gazetted to apply the Administrative Procedures Act of 1966 to the board. ${ }^{98}$ This statutory obligation to give findings of fact and reasons was considered by the Supreme Court of Canada in Northwestern Utilities Ltd. v. Edmonton ${ }^{99}$ in relation to a brief decision of the Public Utilities Board, which is under the same statutory obligation. Estey J. said of it: 100

It is not enough to assert, or more accurately, to recite, the fact that evidence and arguments led by the parties have been considered. That much is expected in any event. If those recitals are eliminated from the "reasons" of the Board all that is left is the conclusion of the Board "that the forecast revenue deficiency in the 1975 future test year requested by the Company cannot be properly characterized as 'past losses' ". The failure of the Board to perform its function under s. 8 included most seriously a failure to set out "the findings of fact upon which it based its decision" so that the parties and a reviewing tribunal are unable to determine whether or not, in discharging its functions, the Board has remained within or has transgressed the boundaries of its jurisdiction established by its parent statute. The obligation imposed under s. 8 of the Act is not met by the bald assertion that, as Keith J. succinctly put it in Re Canada Metal Co. Lid. et al. and MacFarlane, at p. 587, when dealing with a similar statutory requirement, "my reasons are that I think so".

The Alberta Court of Appeal in Re Couillard and the City of Edmonton ${ }^{101}$ considered a similar statutory obligation to state facts and reasons, stressing their importance to a court exercising its supervisory jurisdiction over a tribunal. A Surface Rights Board decision that simply asserts that the totality of the evidence has been considered, and suggests that only the end figure is important, without pointing to the findings of fact on which it relies, and without making a reasoned connection between those findings and the award that it makes, is sure to run foul of these strictures. Their application to the Surface Rights Board, in Whitehouse v. Sun Oil, has been described above. ${ }^{102}$ They are particularly important in the surface rights situation, where the courts are prepared to give considerable weight to the expertise of the Board, but only if the Board's reasons are adequate to show that that expertise was relied upon. This point was made in Chieftain Development Co. Ltd. v. Lachowich ${ }^{103}$ as well as the Whitehouse case.

The second policy factor for discouraging global awards was given in Dome v. Grekul. ${ }^{104}$ That is the policy of the higher courts, now firmly established, that a global award of damages is not as sound as an assessment of damages in separate amounts. This policy was definitively established by the Supreme Court of Canada in Andrews v. Grand \& Toy Alberta Ltd., where Dickson J. said: ${ }^{105}$

The method of assessing general damages in separate amounts, as has been done in this case, in my opinion, is a sound one. It is the only way in which any meaningful review of

98. S.A. 1966, c. 1, s. 8, applied by Alta. Reg. 39/70; now supran. 68 and Alta. Reg. $135 / 80$.

99. Supra n. 69.

100. Id. at 706, citing Re Canada Metal Co. Ltd. and MacFarlane (1973) I O.R. (2d) 577.

101. (1979) 103 D.L.R. (3d) 312 (Alta. S.C.A.D.).

102. Supra n. 67.

103. Supran. 87.

104. Supra n. 73.

105. Supran. 77 at 235. 
the award is possible on appeal and the only way of affording reasonable guidance in future cases. Equally important, it discloses to the litigants and their advisers the components of the overall award, assuring them thereby that each of the various heads of damage going to make up the claim has been given thoughtful consideration.

In Andrews, a personal injury case, even though there was no suggestion in any statute for a breakdown of components (as there is in s. 25 of the Surface Rights Act), the Court divided the claim into four heads: pecuniary loss occurring before the trial, non-pecuniary loss, loss of earning capacity, and cost of future care. In the Court of Appeal, McGillivray C.J.A. had decided that the same approach was necessary, ${ }^{106}$ and English decisions to the same effect were referred to. One of these, George v. Pinnock, ${ }^{107}$ is especially interesting, because the defendant had argued that the injured plaintiff's award for pecuniary loss should not be increased on the ground that, even though the sum allocated to that particular head might have been too low, the total global award was comparable to the combined figures in other cases. The English Court of Appeal rejected that approach. Pecuniary losses could vary greatly in different cases, and the defendant's approach could result in other parts of the award being unduly reduced if those losses were high in a particular case.

In Dome v. Grekul, ${ }^{108}$ Miller J. held that Andrews v. Grand \& Toy applied to surface rights awards and that the lumping together of four heads of damages in one global award was therefore incorrect. In so holding, he brought together the administrative law cases on giving reasons and the torts law cases on the itemization of damages. Standing back a little from the narrow and specific questions, one can see that, in reality, the two strands of legal principle are closely related. Both seek to improve the procedures of tribunals in order to promote a systematic, open and reviewable exercise of decision-making powers. This close relationship is demonstrated by the fact that the same justifications are often cited for each principle. The giving of reasons and the itemization of awards both ensure that decisions are in fact made on a rational basis. The parties have information with which to decide on making an appeal, and a meaningful appeal or review is possible. Guidance is given for future cases and the parties, especially the unsuccessful one, are assured that each individual issue has been duly considered.

Hence, both general principle and legal authority disfavour the global award. The evidence in a particular case may be in such a form that a global award is dictated, as in cases relying on compensation fixed in a pattern of voluntary dealings. In any other case, a global award appears to be unjustified. There may be simple cases where a failure to break an award down into separate heads will not be held to amount to a failure to give reasons, but there can only be a limited field in which this will be the case. Moreover, a decision relying on pattern of dealings evidence cannot be immune from the requirements to give findings of fact and reasons. The courts will expect the Board to give its findings and reasons for accepting the existence of the pattern, the similarity of those negotiated

106. Id.

107. [1973] 1 W.L.R. 118 (C.A.).

108. Supra n. 73. 
agreements to the taking in issue, and the voluntariness of the agreements in coming to the particular figure that it awarded.

\section{CONCLUSIONS}

The main results of this survey will have become reasonably clear. Pattern of dealings evidence is a welcome addition to the techniques available for ascertaining proper surface rights compensation. However, it would be an unjustifiably rigid way of thinking to hold that pattern evidence is the only evidence that should be accepted. All methods should be available for consideration with as few restrictions on them as possible. The global approach, on the other hand, as the assessment of compensation in a lump sum, when divorced from the issue of pattern of dealings evidence, is no more than an attempt to evade a methodical and reasoned consideration of the features of the individual case. It falls foul of statutory obligations to make findings of fact and to give reasons. It cannot be defended by picking faults in any other approach or current practice, or by stressing the difficulty of putting dollar figures on intangible factors.

A continuation of the trends that have been reviewed here poses a sizeable challenge to advisers of operators and landowners alike. We can expect to see more activity from surface rights groups, more area agreements being negotiated to cover large areas, and a continued disputation of the proper method for fixing compensation in each particular case. Like it or not, operators are going to have to be prepared to play the pattern of dealings game. They will need to be ready to test the owner's pattern evidence by cross-examining on the comparability of the agreements making up the pattern, in the same way that an appraiser's evidence is tested; a tactic that Bain's case cannot be said to have prevented. They will need to be ready with their own pattern evidence. Landowners will be obliged to become more selective with the agreements they use, and more prepared to show how similar those cases are to the case in hand. The appraisal profession is going to have to demonstrate some willingness and expertise in pattern evidence if it does not want to be left on the sidelines.

A more general view indicates that the current situation in surface rights law is a most unsatisfactory one. Many more appeals are being made from the Surface Rights Board to the main courts than one would expect from a specialist tribunal of this kind. These appeals are most unpredictable, as there are enormous differences in the figures awarded in different cases. The theoretical basis for fixing compensation has lost all coherence. With respect, it must be said that the policies of the Board on the basis for compensation fluctuate from case to case. The cause seems partly to be the composition and expertise of different panels of the Board, partly a lack of coordination within the Board, and partly the wide fluctuations that occur in the guidance given by the Court of Queen's Bench. Queen's Bench decisions can be cited to support most of the arguments that a party may wish to make to the Board on the correct approach to compensation. (It should be added, again with respect, that the judgments of the Court of Appeal have not suffered from similar fluctuations of policy.) The situation is exacerbated by the frequent will- 
ingness of the courts to disregard the knowledge and expertise of the Board and simply to substitute their own views. The rule in Lamb v. Canadian Reserve Oil and Gas Ltd..$^{109}$ and Caswell v. Alexandra Petroleums Ltd.11 is cited more often than it is followed. Basically, there seems to be a lack of policy direction at the specialist level.

Three main possibilities could be employed to remedy this situation. The first one, usually the government favourite, is to wait and see what will happen under the existing system. The process of litigation would probably resolve difficulties such as the validity of lump sum awards where the nature of the evidence does not demand them, but it would not necessarily bring an end to the divergences of opinion about the proper policies that the Board should follow. Nor would it reduce the number of appeals coming to the courts. A second possibility is to resolve all outstanding questions of policy or principle by legislation. Pattern evidence, or global awards, could be approved, or banned, or given some qualified status in the scheme of the Surface Rights Act. The trouble with this approach is that it would only address the issues of the moment. It would be rigid and it could lead to unpredictable results. Nor could it be expected to abate the number of appeals.

Although the right of appeal may at first glance seem to be a question of procedure and not at all a question affecting the proper principles and policies for fixing compensation, a change to it may in fact be the best possibility for an improvement in policy direction. Presently there is a general right to appeal a compensation order to the Court of Queen's Bench on any question of fact or law. The Surface Rights Board is subject to numerous and of ten irreconciliable expressions of opinion from the Court on the Board's own field of specialization and it is supposed to follow every one of them. Perhaps the Board's knowledge and expertise deserve more recognition that this. The Board should be enabled to settle internally the policies that it should take on pattern evidence, global awards and the four heads approach. Its policy directions should only be altered by the courts after careful consideration on the grounds of misinterpretation of the intent of the statute or other questions of law or jurisdiction. At the same time, the need for suitable skills and experience should be recognized in the making of board appointments, and the Board should have the staff and resources necessary to enable it to carry out the necessary planning and research.

There seems to be a strong case for amending the Surface Rights Act to allow appeals direct to the Court of Appeal with leave of a judge of that Court on a question of law or jurisdiction only. This is the same as the right of appeal that is presently allowed from the Energy Resources Con-

109. Supran. 3.

110. Supra n. 4. 
servation Board ${ }^{111}$ and the Public Utilities Board. ${ }^{112}$ The present general right of appeal was introduced in 1967 at the behest of the Special Committee on Administrative Boards and Tribunals. ${ }^{113}$ The Committee reasoned that a right of appeal was not generally warranted from administrative tribunals, but that compensation cases - including surface rights cases - were different, because of the importance of property interests and the experience of the courts with claims for compensation of every description. ${ }^{114}$ This reasoning does not appear to have been well borne out in the last eighteen years of surface rights appeals.

The greater certainty that owners and operators would gain from such a change would greatly outweigh any benefits that they presently obtain from having a rehearing before the Court, especially since the Board has powers of its own to hold a rehearing in any event. The best way to reduce the current controversies seems to be to reduce the hindrances on the Surface Rights Board; it is the body best able to respond to them.

111. Energy Resources Conservation Act, R.S.A. 1980, c. E-11, s. 44.

112. Public Utilities Board Act, R.S.a. 1980, c. P-37, s. 62. An appeal from the Land Compensation Board is to the Court of Appeal on questions of law and also fact; Expropriation Act, R.S.A. 1980, c. E-16, s. 37. Surface rights appeals in British Columbia lie to the Supreme Court on points of law only; Petroleum and Natural Gas Act, R.S.B.C. 1979, c. 323, s. 24. In Saskatchewan they lie to the Court of Appeal with leave, on questions of law or jurisdiction only; Surface Rights Acquisiton and compensation Act, R.S.S. 1978, c. S65, s. 71 .

113. A Report of the Special Committee on Boards and Tribunals to the Legislative Assembly of Alberta, Edmonton, (?) 1966.

114. Id. p. 77. 